\title{
Effect of COVID- 19 on Motivation and Performance In Banking Industry with Reference to Delhi
}

\author{
Jyoti Bhoj
}

\begin{abstract}
The year 2020 has will be remembered as the year where the entire world was thrown into a chaos by the disease named by WHO as COVID-19. This has made our established structures and norms of organization working out of date. It has affected workers all over the world. In India government has issued many guidelines with respect to working. This study analyses the impact of pandemic COVID-19 on employee motivation and performance.

Keywords: Banking industry, COVID-19, employee motivation, pandemic
\end{abstract}

\section{INTRODUCTION}

COVID-19 which began in Wuhan, China has taken the entire world in its firm grip. This has affected the entire world and humans specially. The year 2020 in its first few months has seen most countries being affected by this disease. The gravity of situation can be understood from the fact that WHO has termed it as "pandemic" and not an "epidemic". Epidemic ailment is one "influencing numerous people simultaneously, and spreading from individual to individual in an area where the illness isn't for all time predominant." The World Health Organization (WHO) further determines plague as happening at the degree of a district or community. Pandemic is additionally utilized as a thing, signifying "a pandemic infection." The WHO characterises a pandemic as "an overall spread of a new sickness" On the date March 11 2020, the WHO formally announced the COVID-19 episode a pandemic because of the worldwide spread and seriousness of situation. As on 28th march 2020 there are 3.04 million confirmed cases with as many as 2, 11,000 deaths. India has also not remained untouched from its impact. As per ministry of health and family welfare the coronavirus cases in India has crossed 21000 mark with states like states like Maharashtra leading the tally with 8590 cases as on 28 Apr. 20 followed by Gujarat and Delhi respectively. As the orders of government of India, India went for a lockdown from 25th, march 2020 which was further extended till 3rd may 2020.

This has a huge implication both social and economical for India. This pandemic itself has led to countries going for lockdown and shutting themselves to save lives of its citizens. "Work from home" has become a part of everyday lives of

Revised Manuscript Received on May 15, 2020.

* Correspondence Author

Jyoti Bhoj*, Research Scholar, University of Rajasthan, Jaipur (Rajasthan), India.

(c) The Authors. Published by Blue Eyes Intelligence Engineering and Sciences Publication (BEIESP). This is an open access article under the CC BY-NC-ND license (http://creativecommons.org/licenses/by-nc-nd/4.0/) many Indians. However stills there are people that are going for work amid this pandemic such as people in medical profession, police, army etc. Many others services providers such as grocery shops, medical shops are kept open for public convenience. People in banking profession providing financial services are also require to go to their offices as per government instructions and guidelines.

\section{A. Banking sector}

The RBI Act of 1934 extensively characterized the Indian financial part into scheduled banks and non- scheduled banks. Former are those that have a paid up capital and gathered assets of more than five lakh rupees and are qualified for advances from the RBI at bank rate. Every other bank fall under the non-schedule classification. There are 34 banks presently working in India. It consist of 12 public sector banks and 22 are private sector banks. The number of employees working in private sector banks in March, 2018 was 420285.000 persons which was just 50,317 in 1992. The following figure show the data with respect to private sector employees.

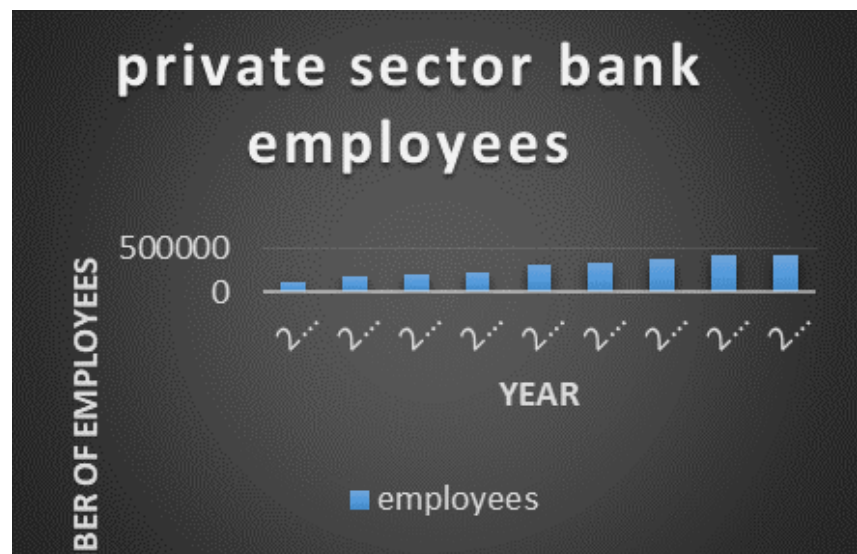

Figure -1: Strength of employee in private sector over the period 2010 to 2018

Source: reserve bank of India

As per the data in 2010 the number of 112207 which increased ever year to reach 319050 in 2015 and to 420285 in 2018. If we look at the public sector banks we see an increase of approximately 250000 from 2008 to 2018.

Published By:

Blue Eyes Intelligence Engineering

\& Sciences Publication

(C) Copyright: All rights reserved.

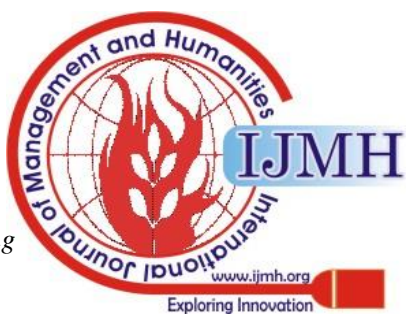




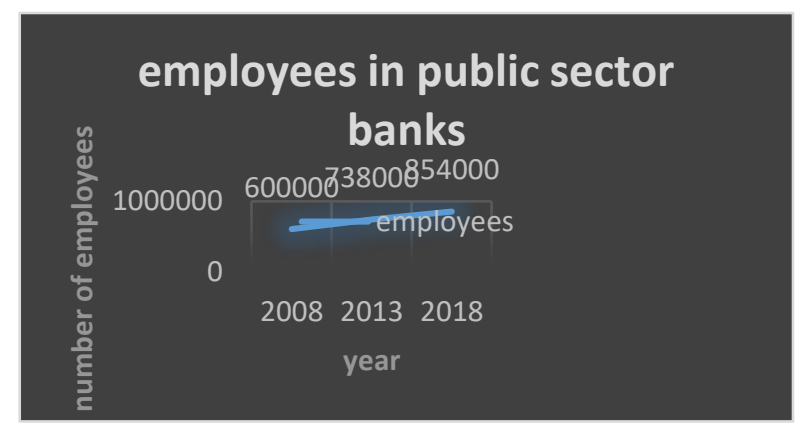

Figure -2: strength of public sector bank employees Source: statistica.com

If we take the case of Delhi 3610 schedule commercial banks were operating in Delhi in 2018.

\section{B. Working amid pandemic situation}

Due to the nature of the financial services provided by banks working from home is hardly an option for bank employees. They have been working and providing their customer financial services. Although banks are require to take appropriate measures for the safety of their employees but working under such situation can affect their motivation and performance. It can put social and psychological pressure on an individual which in turn affect his or her morale and performance. This article probes with how working under such stressful condition is affecting banking employees.

\section{Objectives}

1. To understand the impact of COVID-19 on motivation level of employees

2. To understand the impact of COVID-19 on the performance of employees

3. To understand the satisfaction level of employees with the safety measures taken for their safety.

4. To draw results and conclusion.

\section{LITERATURE REVIEW}

Nurun nabi, tanvir mahady dip, Abdulla, Islam (2017) In "The impact of motivation on employee performances: a case study of Karmasangsthan bank limited, Bangladesh" state workforce is the representatives and core of any association. For any association to work easily and with no interference, workforce collaboration can't be supplanted with whatever else. It is of most extreme significance that the workers of an association not just have a decent connection with the top administration, yet in addition they keep up a solid and expert connection with their collaborators. The accompanying investigation is a self-directed research on how persuasive instruments sway the presentation of worker for improvement. The investigation likewise centered-around de-inspiration factors influencing worker execution contrarily. An example of people was chosen and was met with a self-administrated survey to get essential information. The information was investigated utilizing clear factual examination techniques. The outcomes acquired demonstrate that if representatives are decidedly inspired, it improves both their adequacy and productivity definitely for accomplishing authoritative objectives. CDC (2017) "Get your workplace ready for pandemic flu" by US department of health and home services discusses that most working environment settings have built up a crisis activities plan that tends to a scope of emergencies. Ensure work environment has an alternate course of action that incorporates arrangements and strategies that are adaptable and can line up with future general wellbeing proposals that may happen during a pandemic. Getting ready for and rehearsing crisis activities will help working environment react all the more viably when a real crisis happens. Defend the wellbeing of your laborers, clients, and the network by ensuring your alternate course of action incorporates arrangements for pandemic. In particular, create adaptable approaches and methods that permit laborers and employees to remain at home when they are ill during a pandemic. WEF(2020) in the "Workforce Principles for the COVID-19 Pandemic Stakeholder Capitalism in a Time of Crisis" the unknown waters of this emergency request spryness and advancement, and adjusting to quickly changing frameworks and regulations. Understand the points of view of and connect all partners (e.g., workers, investors, clients, providers, associations, social insurance supplier network) in dynamic. Keep a heartbeat on the moving needs and needs all things considered and the advancing condition of serious and imaginative practices. The cost weight of the present income testing condition places noteworthy weight on pioneers to address the issues of investors when the prosperity of workers, especially the most defenseless and vulnerable, is in effect genuinely compromised. Be that as it may, the dangers to - and advantages of - worker prosperity and company prosperity are exceptionally aligned.

\section{RESEARCH DESIGN}

It tells us about the framework of research. It answers the question "how" will move forward with a research.

\section{A. Research design}

This is a descriptive research. It describes and do not tamper with the event or respondents.

\section{B. Research population}

This research is done on the bank employees working in different branches of Delhi.

\section{Research sampling technique}

Convenience sampling has been used in this research.

\section{Sample size}

A sample size of 29 bank branches were considered for this research.

\section{E. Data collection}

Data is collected with the help of questionnaire. Both primary and secondary data is used in this research.

Published By:

Blue Eyes Intelligence Engineering

\& Sciences Publication

(C) Copyright: All rights reserved.

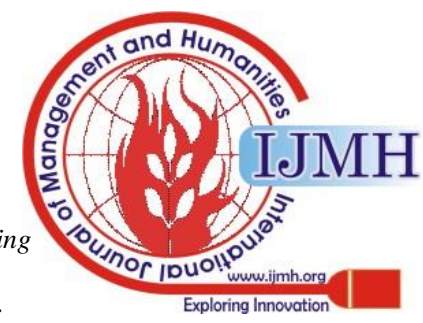




\section{F. Data analysis}

Appropriate data analysis tools are used for this research.

\section{RESULTS}

Data was collected on the motivation level of employees while working under normal and pandemic condition. Paired sample $t$ test was used to test the hypothesis $\mathbf{H}_{\mathbf{0 1}}: \boldsymbol{\mu}_{\mathbf{d}}=\mathbf{0}$

The findings are shown in the table below.

Table-1: Testing hypothesis one using paired sample t test

\begin{tabular}{|c|c|c|}
\hline \multicolumn{3}{|c|}{ t-Test: Paired Two Sample for Means } \\
\hline & \begin{tabular}{l}
\multicolumn{1}{c}{ Before } \\
pandemic \\
motivation \\
level
\end{tabular} & \begin{tabular}{l}
\multicolumn{1}{c}{ After } \\
pandemic \\
motivation \\
level
\end{tabular} \\
\hline Mean & 7.103448 & $7^{6.58620}$ \\
\hline Variance & 7.881773 & 8.82266 \\
\hline Observations & 29 & 29 \\
\hline $\begin{array}{l}\text { Hypothesized Mean } \\
\text { Difference }\end{array}$ & 0 & \\
\hline df & 28 & \\
\hline t Stat & 0.969256 & \\
\hline $\mathrm{P}(\mathrm{T}<=\mathrm{t})$ two-tail & 0.340716 & \\
\hline t Critical two-tail & 2.048407 & \\
\hline
\end{tabular}

The mean motivation is slightly higher in before pandemic. The variance also show small difference. The $\mathrm{p}$ value is 0.340716 which is greater than $\alpha$ value of .05 than the null hypothesis is accepted. Our second objective tries to understand the impact of COVID-19 on the performance of respondents we are testing the second hypothesis $\mathbf{H}_{\mathbf{0 2}}$ : $\boldsymbol{\mu}_{\mathrm{d}}=\mathbf{0}$

Table-2: Testing hypothesis two using paired sample $t$ test

\begin{tabular}{|c|c|c|}
\hline \multicolumn{3}{|c|}{ t-Test: Paired Two Sample for Means } \\
\hline & $\begin{array}{c}\text { Performan } \\
\text { ce before } \\
\text { pandemic }\end{array}$ & $\begin{array}{c}\text { Performan } \\
\text { ce after } \\
\text { pandemic }\end{array}$ \\
\hline Mean & 7.965517 & 7.310345 \\
\hline Variance & 6.248768 & 7.293103 \\
\hline Observations & 29 & 29 \\
\hline $\begin{array}{c}\text { Hypothesized Mean } \\
\text { Difference }\end{array}$ & 0 & \\
\hline df & 28 & \\
\hline t Stat & 1.511559 & \\
\hline P(T<=t) two-tail & 0.141851 & \\
\hline t Critical two-tail & 2.048407 & \\
\hline
\end{tabular}

The mean show slight variations. By comparing the $\mathrm{p}$ value 0.141851 with $\alpha .05$ we reach at the result that null hypothesis i.e., the pandemic do not impact the performance is accepted.

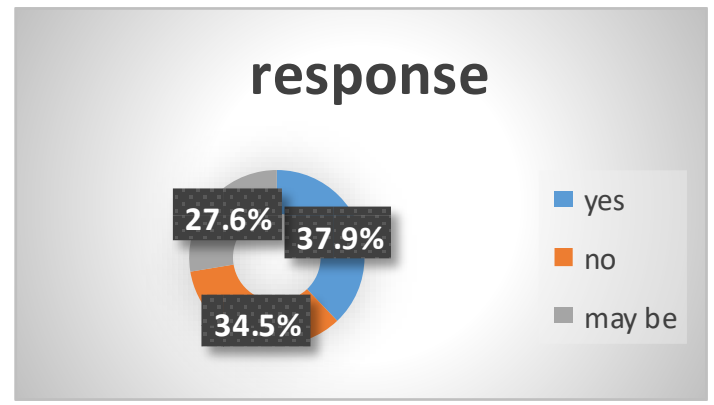

Figure-3: Respondent on appropriate safety measure taken

A majority of $37.9 \%$ believed the organisation has taken appropriate safety measure for them while some $27.6 \%$ were not sure and a $34.5 \%$ responded in negative. The respondents were asked whether appropriate safety measures taken by their employers and to rate the same on a ten point Likert scale.

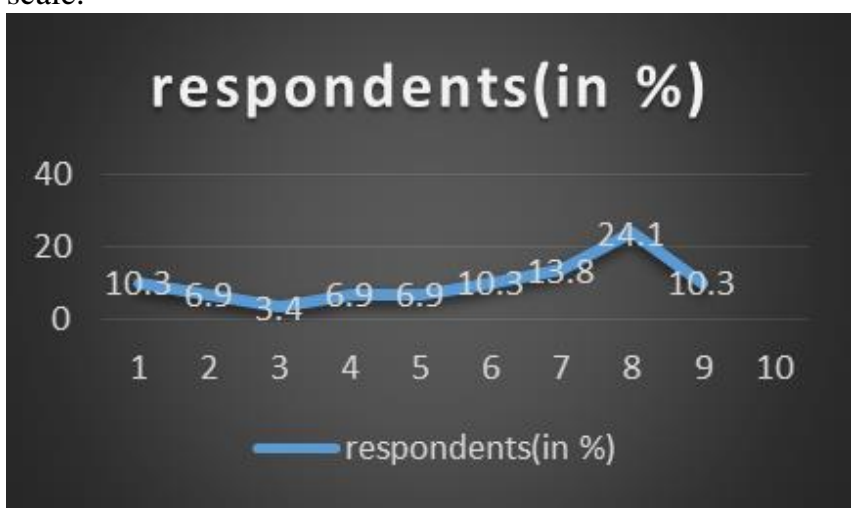

Figure- 4: Rating of safety measures by respondents

In the above figure more than 50 percent of the respondents have given a rating of their organisation above 5 points in Likert scale. A highest of 24.1 percent has given 8 as rating on a scale to ten whereas 27.5 percent has given a rating of less than 5 on Likert scale.

\section{CONCLUSION}

The covid-19 pandemic has affected the whole world. This can be termed as a "health emergency". These challenging times is affecting everyone. The disease with no vaccine till now is affecting individuals economically socially and psychologically. The front line workers are performing beyond the expectation working hard for saving lives and providing citizens with essential services. Such challenging situation require flexibility and innovation on the part of organization to ensure the health of employees and still provide services to customers. In the case of India which is a developing nation, we do not have the required infrastructure as possessed by developed nation such the importance of care vigilance and precaution required here for employee safety is higher. The bank cannot go for work from home for maximum of its activity. A bank even at the time of pandemic is seeing footfall which is lesser but still present thus making bank employees vulnerable.

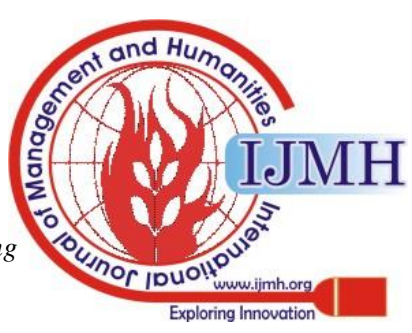


This study is conducted to understand the Effect of COVID-19 on motivation and performance of bank employees. This the present study it is found that although bank employees are concerned about their safety and with many living in containment zones that has not affected their performance and motivation. There can be various reasons for the same for example the times of emergency channels a sense of responsibility to do something for your country especially in case of Indians it triggers an attitude of love and service for our country. Second is the rapid actions and directions given and executed by the centre and state government. The last year in India witnessed a cold war between many state and centre government however in the case of this pandemic Indians saw cooperation at its highest between them thus boosting the confidence of citizens. Health ministry is quite active in this pandemic and issuing precautions and prevention measures. The center has also issued guidelines for employees on functioning of organizations. Many banks are adhering to the guidelines and taking precautions for their employee safety. Much more needs to be done but the efforts of bank organizations and their employees services to the citizens is praiseworthy. With that said online workshop on precaution while dealing with customer, safety kits, keeping employees aware about latest information and stress relieving activities should be promoted. of the work or suggest applications and extensions.

\section{REFERENCES}

1. WEF, "Workforce Principles for COVID-19 Pandemic stakeholder capitalism in atime of crisis," wills tower watson, 2020.

2. CDC, "Get Your Workplace Ready for pandemic flu," centre for disease control and prevention, 2017.

3. ILO, "COVID-19 and the world of work: impact and policy responses," geneva, 2020.

4. http://www.mospi.gov.in/national data bank

5. https://www.statista.com/statistics/1034802/india scheduled commercial bank offices Delhi

\section{AUTHORS PROFILE}

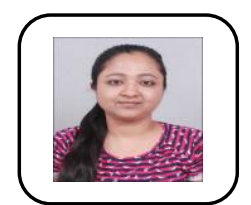

Jyoti Bhoj, The author is a research scholar in university of Rajasthan, Jaipur. She has submitted her thesis in December 2019. Her topic of research is "a study of regret aversion and false reference points in residential real estate with reference to Delhi- NCR" Her research focus on regret aversion and false reference points taken by investors in residential real estate. It study the impact of gender, education, marital status and income on regret aversion. This study also analysis the difference in regret aversion when house is purchased for investment from when it is purchased for self- residence. She has keen interest in research and has written various research articles.

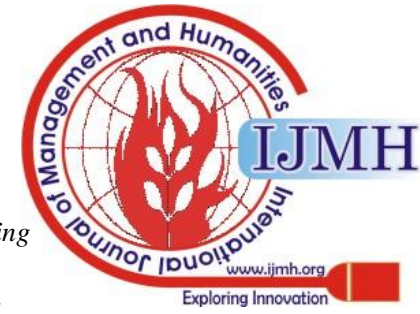

